\title{
Contemporary Security Challenges in Nigeria: Historicising the 1931 'Ogun Okuta' (Stone War) in Akure
}

\author{
Adedayo Emmanuel Afe* \\ Adekunle Ajasin University \\ Akungba-Akoko, 23434, Nigeria
}

Received 23.03.2016, received in revised form 26.04.2016, accepted 19.05.2016

The Native Authority Revenue Ordinance of 1917 introduced a direct tax system to Southern Nigeria for the first time. This development was greeted with resistance by people in some towns, such as Aba, Iseyin and Akure, among others. The collection of taxes led to a war popularly known as 'Ogun Okuta' (Stone War) of 1931 in Akure and its environs. This paper discusses the role played by the Deji (Diadem) of Akureland, Oba Afunbiowo Adesida I, in the crisis. This study is imperative because Oba Adesida's reign has been described severally as peaceful, but findings show that his subjects humiliated him for his alleged role of collaborating with the British officials in the imposition of the insuperable tax on his subjects. This study also revealed that there were other associated factors that contributed to the revolts that greeted the tax imposition. The methodology adopted for this work is critical analysis of materials, drawn from oral and written sources. This study found that, it is believed that the British intervention aggravated the internal crisis within the kingdom. The paper concludes that Nigerian internal security issues should be managed by the Nigerian government instead of resorting to external military or intelligence support.

Keywords: Tax, Crisis, War, Resolution and Monarch.

DOI: 10.17516/1997-1370-0029.

Research area: history.

\section{Introduction}

All states or polities have witnessed one event of conflict or the other. In other words, the contemporary security challenges ridding the African continent as it is the case of Nigeria, is definitely not entirely peculiar to the postindependent period. The eve of colonial rule, especially during the forceful acquisition of territories, when European states through means other than negotiation imposed their authority on pre-existing political administrations in African politics, was characterized by varying degrees of conflict. The same was also the case during the establishment of colonial administration various territories such as the Gambia and the British Gold Coast (modern Ghana), when new policies and systems of administration, prominent among which was taxation were initiated. Definitely, this precipitated internal discontents among the people who found the exorbitant rates and taxes

(C) Siberian Federal University. All rights reserved

* Corresponding author E-mail address: adedayoafe30@gmail.com 
to be exploitative and inconsiderate, considering their relatively meager income or livelihood. The extreme scenarios of this discontent are cases of conflict, characterized with violence and social disturbances.

Threemonths afterhis ascension to the throne, the missionaries led by the late Rev. Ogunbiyi of the CMS had entered Akure for the first time ever (Akintide, 2009). The new Deji, Afunbiowo Adesida the First, knew he had to specially woo the new missionaries because he clearly saw them as a mighty wind of change that would transform Akure forever, and he was right. Oba Afunbiowo sided with the colonial Government when they introduced, for the first time, in Akure history, official tax collection from Akure people. This tax was seen as oppressive and the people rioted against him in what is now referred to as "Ogun Okuta" (the Battle of the stone pellets) in Akure, when the Palace was placed under siege and Kabiyesi (one whose authority is unquestionable) himself was stoned by his own people for his decision to side with the colonial Government for introducing tax collection by force. The Deji did not budge but effectively quell the insurgents and to put down the rebellion.

On the eve of the British administration in Akure, precisely in 1897, a detachment of Hausa Constabulary was stationed in Akure under Lieutenant A.O.C Scott (Afe 2012, 200-201). Eight officers were in charge of the detachment until it was withdrawn in March 1900, as a result of the formation of the North Eastern District of the Lagos Government in 1899 in which Akure was place. In June, 1901, the Akure District was transferred to the Eastern Division with Headquarters at Ondo. The Native Authority Ordinance of No. 14 of 1916 formally constituted Native Authorities in Akure and other Western Provinces (Afe 2012, 201). However, after main changes in the British Colonial Administrative in Nigeria, the Akure District was merged with the newly constituted Ekiti Division and Akure was made the headquarters of the then newly created Ondo Province. Thus, Akure District continued to be governed as part of Ekiti Division until April, 1946, when it was separated after a fierce struggle. When Ondo State was created on February 3, 1976, Akure became the State Capital. The Ogun Okuta case in the Akure division of Ondo Province, Southern Nigeria stands out in the discourse of conflict for two obvious reasons. First, it was the first indigenous revolt against the colonial government in Akure, which escalated as a result of the obnoxious tax regime of the British officials and their collaborator (Oba Afunbiowo). Second, the factors that have precipitated this crisis can definitely be likened to the same factors that have influenced the Niger-Delta crisis (the conflict in the oil-rich Niger Delta Area of Nigeria which arose in the early 1990s over tensions between foreign oil corporations and a number of the Niger Delta's minority ethnic groups who feel they are being exploited, particularly the Ogoni and the Ijaw) in contemporary Nigeria. The collaboration between the Federal Government and the multinational corporations in the Niger-Delta has been attested as the factor that influenced the development of insurgency in this region of the country. These factors have definitely influenced the need to historically investigate the Ogun Okuta crisis in Akure. A study of this similitude will definitely provide highly pragmatic recommendations on the means to resolute conflict and in that same vein provide the basic historical knowledge of Colonial Akure.

\section{Theoretical Framework}

This study has been carried out with the use of Marxist theory from the perspective of Jean Charles Leonard de Sismondi. The theory became prominent in the midst of growing capitalism in the world. The theory was based on 
equal balance in capitalist economy. Karl Marx opined that as the gaps between the bourgeoisies (rich) and the proletariat (poor) are becoming wider, the tendency for the rich to subjugate the poor perpetually would be the basis for crises in the capitalist economy (Marx 1993, 495-496). He argued that the rich would want to maintain their positions and the poor would want to change the status quo. He believed this would not happen naturally without the use of force. Jean Charles Leonard de Sismondi showed clearly the untenability of the doctrine that competition always tends to establish equilibrium between production and consumption. More specifically he emphasized that general crises are not only possible but an inevitable periodic concomitant of the prevailing economic structure. The direct cause of such crises he found in underconsumption on the part of the working classes, whose purchasing power is insufficient to absorb the annual national output (Grossman: 1934). In the process of applying force, in order to make their condition or plight known, crisis may arise (Schumpeter 1994, 139).

That is, the social infrastructure that has been built for years might be destroyed by the poor in order to press home their points and demands. There is a point of convergence in the views of Marx and Schumpeter. The poor in an attempt to cross their level of economic poverty would be resisted by the rich, and the poor would not naturally agree. This will bring about struggles that would normally lead to crisis (Harns 1942, 805-835).

The theory can be applied in all the nations of the world where capitalist economic system is in practice. For example, in Nigeria, the rich are becoming richer because they have access to power and could influence their way through. In the sense of this theory, the political elite represent the bourgeoisie while the poor are the proletariats. The bad economic policies may not have much effect on the political class because they have access to the nation's wealth. The poor who bear the brunt of the policies would always resist through staging of crises, demonstrations, etc., to express their poverty, neglect and joblessness.

\section{Conceptualization of Major Terms}

History has shown that human societies in most cases are unable to either manage conflicts or gain the benefits of mutual evidence. This human inability mostly gives room for conflicts to lead into crises. Consequently, these crises are often resolved, or at least ended without war, but sometimes they are not, and instead they escalate to war. In discussing the issue of this nature, it is imperative to conceptualize some fundamental terms used as they are very vital. Among the key concepts that need to be properly conceptualized are:

\section{Crisis}

According to Reinhart Koselleck, crisis can indicate a state of greater or lesser permanence, as in a longer or shorter transition towards something better or worse or towards something altogether different. "Crisis" can announce a recurring event, as in economics. Reinhart Koselleck has written at length on how the meanings of crisis and referents have varied across time and space (Koselleck 1988, 45). To confirm this, one was confronted by an endless parade of politicians and pundits invoking the concept in certain ways, such as: a crisis of confidence, a crisis of finance, a crisis of neo-liberalism, and a crisis of sovereign debt; a crisis of European integration, a crisis of North African dictatorship, a crisis of Western foreign policy, a crisis of global capitalism etc. Within the academia, however, the idea of 'crisis' has been used to identify different periods in world history, and to account for specific pathways of institutional transformation; to describe the 
contradictions that underpin the failure of a political or economic system to function; and to understand the interpretive struggles triggered by the acknowledgement of such failures (Crotty 2009, 563-580). In other words, the crisis that broke out in 1931 could be attributed to the colonial institutional failure in Akure. In other words, the crisis that broke out in 1931 could be attributed to the colonial institutional failure in Akure. The natives developed their respective communities through communal efforts while the colonial government did little to nothing to alleviate the suffering of the masses. That is, the crisis over taxation was caused as a result of corruption which largely hinders the political class to judiciously use the people's taxes for the development of their community. As a corollary, the people perceived the demand for more taxes by the colonial administration as a repressive system that needed to be challenged.

\section{War}

Martin Van Creveld, one of the world's most eminent military historians and strategic theorists, defines war as organized violence aimed at achieving economic, social or political ends (Steven and Phillip, 2010). War could also be said to be a weapon which can be used for good or for bad purposes. Some of these purposes for which war has been used have been accepted by humanity as worthwhile ends. Indeed, war performs functions which are essential in any human society. It has been used to settle disputes, to uphold rights and to remedy wrongs. According to international law, war, in principle, can only take place between sovereign political entities, that is, States. War is thus a means for resolving differences between units of the highest order of political organization (Johan 1981, 128-189).The majority of those who have been concerned with war as a socio-political phenomenon have also adopted as their basic premise that there is a fundamental difference between domestic conflicts, for which there are normally mechanisms for peaceful resolution, and international conflicts, which occur in a state of anarchy. Wars have been seen to directly involve State institutions (Aron, 1966).

Von Clausewitz opined that war is an act of violence intended to compel our opponents to fulfill our will. However, Kallen criticizes Von Clausewitz's definition of war as "an act of violence for the purpose of compelling the enemy to do what we will" as too general and indefinite. He says that "this definition might apply also too much that is called peace, particularly in sport, business and finance. It might apply to anybody's act of violence, whenever it occurs. As limited to war, it applies to pre-Napoleonic and pre-industrial times and intentions, when war was a castle enterprise, and a gentleman's game" (Kallen 1939, 373). Moreover, the School of Political Realism maintains that Nation-states can only realize their national interests by demonstrating their willingness to fight and by making use of wars of various degrees or magnitude as an instrument of national policy to achieve legitimate ends (Lider 1977, 7). Although the 1931 violence in Akure had no characteristics of war (i.e. organized conflict), it was however regarded by the Akure people as a war because it involved the use of force such as stone pellets and violent mass protest in achieving their objectives. In other words, the natives who were majorly farmers regarded the request for more taxes by the king together with their lack of readiness to pay as a situation of war whereby force was needed to compel the political class to accept their decision which was the payment of three shillings instead of six shillings. Thus, the use of stone in attacking the ruling class came to be known as Stone War as this strategy temporarily compelled the king and the British Officials to do the people's will. 


\section{Resolution}

In the simplest form, resolution can simply be said to be the act or process of analyzing and resolving a complex notion, competitive or opposing action, divergent ideas, views and interests, into simpler forms. In other words, resolution is all about bringing understanding and peaceful settlement to deeper struggles over unsatisfied human needs and widest set of circumstances in which parties in conflict perceive that they have mutually incompatible goals. This act gave birth to the concept of conflict resolution, which as a sub-field of study is a gradual and systematic process of settling dispute without having to embark on war. In addition, resolution means transforming what was unbalanced relationship into peaceful and dynamic one. Conflict resolution therefore is a systemic passage through which conflicts passed through from unpeaceful to peaceful relationships and may involve a temporary increase in overt conflict as people become aware of imbalances of power and injustice affecting them. The stages of resolution include education or conscientization which is when conflicting parties organize themselves and articulate their grievances. The second stage of resolution is confrontation, which is, coming to terms in a more equal way with those who held a preponderance of power over them which are followed by negotiation and finally join in restructuring a more equitable and just relationship. On the other hand, it can be viewed as a non-violent process that manages conflict through compromise, or through the assistance of a third party who either facilitates or imposes a settlement or resolution (Tillet, 1998). Conflict resolution processes are many and varying, and can be seen on a continuum ranging from collaborative, participatory,informal,non-binding processes (such as mediation, conciliation, third party negotiation) to adversarial, fact-oriented, legally binding and imposed decisions that arise from institutions such as the courts and tribunals (Boulle, 1996, 9). Oba Afunbiowo Adesida although could neither read nor write yet brought understanding and peaceful settlement to the crisis. He deployed his legendry accommodating disposition, liberalism, diplomacy and traditional wisdom into solving the crisis without having to internationalize the conflict. In other words, the king through his ingenuity transformed what was an unbalanced relationship between the ruling class and the people into peaceful and dynamic one by employing traditional mechanism of peace resolution of conflict.

\section{Monarchy}

Modern Nigeria encompasses lands traditionally occupied by highly diverse ethnic groups with very different languages and traditions. Although political structures differed widely between different ethnic groups, it was common for each town or collection of towns to have a recognized monarch, who might in turn be subordinate to the ruler of a larger polity (Djebah, Edomaruse, Issa-Onilu, et. al. 2003). The word monarch comes from the Greek word monárkhēs (monos: "one or singular" and arkhon: "to rule" or "leader or ruler or chief"), which referred to a single, at least nominally absolute ruler. Nigerian traditional rulers often derive their titles from the rulers of independent states or communities that existed before the formation of modern Nigeria. Although they do not have formal political power, in many cases they continue to command respect from their people and have considerable influence. In hereditary monarchies as in Nigeria, the office is passed through inheritance within a family group. It is often connected to sacred functions, so that the king acts as a priest, or is considered of divine ancestry. In the pre-colonial Nigerian society, Afe and Adubuola opined that a king was identified as the most supreme or paramount sovereign in any village, town or city. Generally, 
he was recognised by his subjects as their spiritual leader and Chief Custodian of traditions (Afe and Adubuola, 2009, 2). Pre-colonially, people were governed by their Monarchs who managed inter-village diplomacy, carried out the will of the people and prevented tyranny prior to the intrusion of the British, who also created some new kings and kingdoms from existing one.

Most monarchs, both historically and in the modern day, have been born and brought up within a royal family, the centre of the royal household and court. Growing up in a royal family (when it continues for several generations it may be called a dynasty), future monarchs were often trained for the responsibilities of anticipated future rule. Different systems of succession have been used, such as proximity of blood, primogeniture, and agnatic seniority (Salic law). While most monarchs have been male, many female monarchs also have reigned in history; the term queen regent refers to a ruling monarch, while a queen consort refers to the wife of a reigning king. However, a regent may rule when the monarch is a minor, absent, or debilitated. In Africa, monarchy was predominant. Among them were the kingship of Benin and Oyo in West Africa and Bunyoro in Kitara, East Africa. In West Africa, before the 20th century, kings were regarded as supreme rulers, who had both power of life and death over the people. In Benin for example, the institution was such that every $O b a$ was seen as the owner of the Kingdom who had the final say over every aspect of the lives of Benin people. For instance, if an $\mathrm{Oba}$ was on his forecourt, any citizen who walked pass must stop to greet him. Therefore, any beautiful woman that catches his eyes might become his wife. In this case, if the woman was married, an 'Aroko' (material message) would be sent to the husband to indicate the divorce and remarry of his wife, he would however though be compensated since it is the generally accepted belief that the king owns the land and the people therein. However, many of these monarchs are checked by organs instituted to prevent abuse of power. Such measures include taboos which outline some dos and donts to the king while the breach of such taboos attracted criticism and boycott of the king's palace by his chiefs. In a constitutional monarchy, the monarch is subject to a constitution. The monarch serves as a ceremonial emblem and symbol of national unity and state continuity. The monarch is nominally sovereign but the electorate, through their legislature, exercise usually limited political sovereignty. Constitutional monarchs have limited political power. Thus today a constitutional monarchy is also a limited monarchy, as the constitution limits them in the functions they perform. A constitutional monarchy, then, can be defined as a state which is headed by a sovereign king who reigns but does not rule (Bogdanor 1995, 1). Conventionally, a king could declare war and make peace, conclude alliances, send and receive ambassadors, levy taxes, administer justice and appoint subordinate officials (Oguntomisin and Ademola, 88). In other words, the Deji has the power to confer chieftaincy title on individuals, levy taxes, punish offenders as well as bless the people during cultural festivals since he was regarded as 'Igbakeji Orisa' (second to the Supreme deity) while an order of Deji is of high magnitude and must be strictly adhered to, anyone who flouted their laws might be executed. This was the case in Akure during the period under review when the Deji of Akureland, Oba Afunbiowo Adesida I collaborated with the British officials in the imposition of the insuperable tax on his subjects. This however resulted in stiff resistance by the people and consequently led to the Stone War of 1931. The unanimous decision made by the king to accept from the British officials without proper consultation with his subject the new repressive tax system ultimately led to the crisis. 


\section{$\operatorname{Tax}$}

Tax can be said to be a charge, usually the money imposed by authority on persons or property for public purposes. In the Organisation for Economic Co-operation and Development (OECD) classification, the term "taxes" is confined to compulsory, unrequited payments to general government. Taxes are unrequited in the sense that benefits provided by government to taxpayers are not normally in proportion to their payments. Although, there was a simplified type of tax dating back to 1927, northern Nigeria was the first of the region to levy direct personal taxation under the Fulani Emirs, prior to the advent of the British. In the system, a kind of minimum tax was levied per head. This was extended to southern Nigeria in 1914 after amalgamation. In other words, the head tax which caused the crisis was a variant of taxation imposed at a flat rate on male and female adults who are not government workers that pay as they earn. However, persons or group of people who earn income but whom either or refuse to pay are served with appropriate sanctions, including prosecution. The new system aimed at unifying all existing form of taxation across Nigeria during this period.

To bring orderliness and tranquillity back, resolution needs to be effected. Such resolution during this crisis was the payment of the stipulated tax after series of dialogue with the aggrieved individuals and parties. Resolution between two parties in conflict can only occur when "relationships have been re-examined and realigned. Although this form of resolution may be regarded by some as more desirable; it is not always practicable. Resolution of cases of marital separation or divorce can in some cases simply mean the settlement of an outstanding property dispute rather than the realignment of relationships". The transformation of relationships may be an ideal pursued by a third party who is intervening on behalf of the disputants, but it is not necessarily the goal of the disputants who may simply desire a solution to theirproblem. Therefore, conflict can only be considered resolved if the solution jointly satisfies the interests and needs of the parties via joint agreement. The resolution should not compromise the values of either party. Furthermore, parties are not expected to repudiate the solution, even if they have the power to do so following the settlement. It is only then that such solution is seen as fair and just, and becomes self-supporting and self-enforcing. Although this form of resolution seems ideal because it aims to achieve an enduring outcome, it is not always practicable in situations where the relationship between two parties is severely strained or when there is no ongoing relationship to be maintained. More so, monarchy, which is a government, having a hereditary chief of state with life tenure and powers varying from nominal to absolute is a common phenomenon in the world with a long history as many societies have one time or the other adopted it as their form of government which consequently makes it a universal concept. Since the earliest past, monarchy has contrasted with forms of democracy, where executive power is wielded by assemblies of free citizens. While some monarchies are hereditary, some are nonhereditary. In an elective monarchy, monarchs are elected, or appointed by some body for life or a defined period. Conventionally, a king could declare war and make peace, conclude alliances, send and receive ambassadors, levy taxes, administer justice and appoint subordinate officials.

\section{A Brief History of Akure}

The contemporary Akure is a city in southwestern Nigeria and is the largest city and capital of Ondo State while the people are of the Yoruba ethnic group. Akure is geographically located on latitude $70^{\circ} 20^{\prime} \mathrm{N}$ and longitude $50^{\circ} \mathrm{E}$ and is easily accessible to other major urban centers 
in the state, such as Owo in the East, Ado-Ekiti in the North and Ondo in the South, all within $50 \mathrm{~km}$ radius. Within $100 \mathrm{~km}$ radius are the towns of Ikare, Ikole, Ekiti, ljero Ekiti to the North and Okitipupa in the South. The topography of the town is relatively flat while Akure is connected to other parts of the country by road network system (Ogunbodede and Aribigbola, 2003, 305-322).

The date of founding of Akure cannot be asserted, however, history has it that the town had been firmly established by AD 1440 (Akintade, 2007). Like other Yoruba Kingdoms, a history of Akure is linked with Ife. To the people of Akure, Ife is the sacred spot where ruling classes evolved from, to inhabit the present location. Ife was regarded as the fountain and sources of culture and civilization between the ethnic and sub ethnic groups in Yorubaland. There are different sources of origin of Akure history. One of the oral traditions state that Akure was founded by a prince named Omoremi, son of Ekun and grandson of Oduduwa Omoluabi, the royal progenitor of the Yoruba tribe (Atandare). The Prince left Ile-Ife, his grandfather's kingdom, in search of a place to settle. At the point where the prince and his party arrived at the exact location of the modern Akure city, the string holding the heavy royal beads on his neck is said to have snapped, thus causing the people to exclaim "Àkún re" (meaning: the beads have snapped). This later becomes the name of the settlement they established on the site. Over time, the phrase was whittled down through its constant use to become Akure.

Another Akure legend asserted that Asodeboyede, the first Deji of Akure was the post-humour's son of Ekun, who was the son of Oduduwa, the progenitor of the Yoruba group (Interview with Afe, 2003). Asodeboyede, after the death of his father, (Ekun) continued to live with his grandfather Oduduwa at Ife where he was thought the intricacies of kingship. Being a hunter, Asodeboyede, on his adventure in search of a kingdom, was informed by Ifa oracle that he would permanently settle down wherever he would kill an elephant. Subsequently, he killed an elephant at a distance of six kilometres from the present location in Akure and he promptly remembered the words of the If $a$ oracle and settled there (Interview with Afe, 2003). However, the name Akure came into being when Asodeboyede butchered the elephant and the thread that knitted the beads on his wrist (which was the symbol of princehood) snapped. Therefore, he called the place Akure (Akun-re) meaning, the place where my bead was snapped. Akun-re was later shortened and translated to Akure. However, there was no convincing evidence to support this genealogy. This claim has been controversial and it had led to much argument in some quarters. The reason given was that the name Ekun has not featured prominently in Yoruba history.

Villages under the political suzerainty of Akure in the 19th century were about one hundred and thirty. These villages varied in size. These villages were not allowed to approach the Deji directly because of the discrimination that existed between the metropolitan citizens and the citizens of the satellites whom they usually referred to asira-oko (rural people). Nevertheless, all the village heads under the political jurisdiction of the Deji carried him along in the administration of their different villages. The chiefs and village heads made laws not only for the maintenance of order in their domains, but also for regulation of economic activities of the villages.

Akure people cultivated crops, rear animals as well as other birds both for consumption and commercial purpose. The people employed different farming methods in their economic activities among which was shifting cultivation whereby lands were deliberately left alone for a longer period of time for them to regain their nutrients. More so, there were nearby farms called Oko-Etile or Oko-Aba and distance farms 
called Oko-Egan (Interview with Arifalo, 2009). Hence, at the distance farm, people cultivated crops like kola nuts, bitter kola, and plantains while at the nearby farms, they planted early yams, cassava, vegetables. There were also edible fruits for the people. The women and their children were not left out in the farming system. The women assisted their husbands in harvesting crops and carried them home while some were either exchanged for the commodities they could not produce by themselves or sold at an amount of money. In addition, there were many local industries in the pre-colonial Akure kingdom. These included blacksmithing, weaving, dyeing, calving, leather works and oil palm industries. Based on the fact that Akure was surrounded by large traces of tropical forest reserves, it constituted an extensive timber industry.

Religion also played a crucial role in the political administration of pre-colonial Akure. Akure indigenous traditional religion was and still is based on the belief in the supreme deity. The people also believed in divinities, ancestral spirits, moral, orders and life hereafter. The divinities that were common among Akure and her neighbours were Ogun (god of iron) and Egungun (masquerades). However, it is important to know that the number of adherents of traditional religion in Akure has reduced drastically due to the advent of foreign religions like Christianity and Islam coupled with Western civilization and modernization.

\section{Ogun Okuta:}

\section{Immediate and Remote Causes}

By the Native Authority Revenue Ordinance of 1917, a direct tax system was introduced into the Southern Provinces of Nigeria by Lord Lugard, the Governor-General of the amalgamated Northern and Southern Protectorates. First it came into the Western provinces excluding Asaba and Warri Divisions due mainly to the absence of recognised central authority. At first, there was surprisingly little opposition and very passive resistance to the innovation as people were not willing to part with more of their income. People appeared to have watched in anticipation of what was actually coming. Isolated instances of problems ranging from public condemnation of the tax to mass protests to the king's palace arose at Abeokuta, Iseyin and at Ikirun. But none of these was of sufficient proportions to make the colonial administration re-examine its position (Elias, 1963).

In 1927, the Ordinance was extended to Asaba and Warri Area. Protests and demonstration resulted, in which one died at Sapele during mass protest. In 1928, the Revenue Ordinance had been extended to cover the Eastern Province of the country. More violent reactions like destruction of public properties were to occur in these parts. Large scale disturbances such as mass protests and riots occurred in parts of south-eastern Nigeria such as Calabar, Owerri and Aba. At Aba for example, thousands of angry women carried sticks and cudgels demonstrated against the Chief and the agents of the Warrant Chief (Ellis, 1970). The warrant chief system emanated as a matter of necessity from the lack of pre-existing chieftaincy traditions in some parts of Nigeria such as the Igbo region of eastern Nigeria, which had no tradition of chieftaincy intuitions. The British appointed willing participants or collaborators and gave them "warrants" to act as local representatives of the British administration among their people. Many police officers had to be called out for the safety of the Chief and the agents and for putting down the uprisings.

In Akure, collection of taxes led to a crisis popularly known as Ogun Okuta of 1931. This was a battle between the people of Akure and its environs against the colonial government over the issue of 'head tax' which the people thought was being paid to the Deji, Oba Afunbiowo Adesida 
I, and that he single-handedly spent the money (Esemokhai, 1986). According to Atandare, an accomplished historian, it was a general practice of all the Customary Court Clerk at this period that when anyone wanted to file a case, the litigant must bring six shillings for the form, some tubers of yam, a cock, a load of firewood and a big bottle of locally made gin before his case could be heard in the Court. This made life hard for the people and made some people to report the case to the District Officer (D. O.), Mr. G. G. Harris at Ado-Ekiti who issued a query to one of the court clerks involved, Mr. F. S. Adeoba. It was at this period, July 1, 1931, that Adeoba the court clerks informed the king that the payment of six shillings 'head tax' was to begin, which made the people of Akure to rise against it. They thought that all their communal projects were done through self-efforts. They began to ask the question as to what had the king done for them with the taxes collected so far? Many of the leaders of the revolt were not only aggrieved because of the tax increment, but also because of the benefits the princes and princesses enjoyed the period. It was argued that the community money was used to sponsor the princes and princesses to schools. The decision and determination to wage a war of emancipation from taxation became the household word in Akure and its environs, but the Deji continued to appeal to the people by making the people to understand that the tax was not imposed on them by him. Yet, instead of listening to the king, the people became more antagonistic through continued protests and attack on the colonial officials.

During a meeting between Akure people and the District Officer, the spokesman of the people Mr. Akomolede asked the D. O. what had the king done with the taxes collected every year? Why should the people pay taxes that would be embezzled "by a man? He concluded that unless the Deji could agree that each person should be paying three shillings, if not, the people would pay nothing because they did not buy their heads from anyone". The response of the District Officer was that the people of Akure did not understand the rationale behind taxation. The officer explained that it was not the king that collected the taxes but the government and that if their communal jobs were being done by themselves then, a time would come when the government would take over its responsibilities (Fadipe, 1970).

On July 27, 1931, the D. O. in the company of Native Authority Police and tax collectors assembled at the Akure Native Court No I Hall with $O b a$ Afunbiowo in attendance. They sent to the Akure people to pay their tax - a directive with which minority of the natives complied. The spokesman; Mr. Akomolede was brought to the D. O to pay the reduced tax of five and half shillings. He refused and asserted that he could only pay three shillings. Because of this, he was arrested by the N. A. police. The news of his arrest spread like wild fire (Obaro and Crowder, 1970). On hearing this, the people of Akure threw stones at the king Deji Adesida I and the Resident, G. G. Harris inside the court (that was where the nomenclature of the war derived from Ogun Okuta), In a fit of anger, they rushed inside the court, turned the tables upside down and disorganised the Court Hall. As a result of this, N. A. police besieged Akure up to August 11, 1931. They spent several months before some of the leaders of the revolt could be arrested and after they had jailed many Akure indigenes and forced many to go on exile. Several farm products; livestock's and other valuable goods were destroyed (Obaro, 2001).

This paper reveals that the 'Ogun Okuta' was not fought primarily against the increment in head tax, hence, other factors such as the benefits the princes and princesses enjoyed the period. It was argued that the community money was used to sponsor the princes and princesses to schools. This agrees with the saying that there is no mono 
causality in history. Issue of tax increment is an immediate cause, but there were other associated factors to the crisis which are discussed below.

Shortly before the uprising, like other towns in Nigeria, Akure was equally affected by the post-world war economic depression between 1929 and 1938. During this period, prices fell so low that primary goods producing countries like Nigeria obtained less for their farm products. Cocoa beans were sold at a very ridiculously low price. It was stocked by the companies that were involved in buying. This led to serious economic downturn, and in any society that is enmeshed in economic crisis, people will naturally be aggressive and impatient. This was visible in the reaction of the people to the call by the leadership of the revolt to disregard the payment of increased head tax (Afe and Okajare, 2001).

Findings also show that the quality of the leadership of the crisis also gave currency to the support it enjoyed from the people. The crisis was led by Mr Akomolede (a court clerk), Odopetu Ajolehinogun (a traditional chief and second in command to the Deji), Dukudu Ologuneyon (a prominent traditional chief) and Osue Eruoba (a prominent High-Chief) among others. These people could be described as community leaders with distinction, due to their metaphysical prowess (the practice of communicate with the spirits of the dead in order to predict or influence the future). These people were vast in the culture and traditional beliefs of the people, most importantly, they belief in the potency of the traditional deity. Their directives had the binding influence on the people as a result of their charisma and leadership qualities. Thus, they were able to challenge the British and $\mathrm{Oba}$ Afunbiowo on the increment in 'head tax'. It is pertinent to note that the king was highly revered within and outside Akure and popularly known as the philosopher King' (Interview with Elder Ojo, 2014). He had an encyclopaedic knowledge of the history and mythology of the Yoruba people. The leadership of the revolt was from different quarters and they used this to mobilize people against the tax increment and the towering aura of the King was insufficient to stop the revolt. The ideology of the leaders of the revolt was influenced by the preceding/similar revolts in Aba in 1929.

Some people, within and outside the ruling house might not be happy that $\mathrm{Oba}$ Afunbiowo had overstayed on the throne. For instance, Oba Afunbiowo's first son Albert Afunbiowo challenged his father on the throne for overstaying on the throne. The king was sixty years old when he ascended the throne of his forefathers in 1897, and by 1931 during the crisis he was thirty four years on the throne and ninety four years old. Naturally some potential claimants to the throne may wish that the king should abdicate the throne, so that they could have their turn to rule over Akure Kingdom. The supporters of his son, Albert therefore could have exploited this crisis to further their political ambition. It is also crucial to state here that $\mathrm{Oba}$ Afunbiowo contested for the throne thrice before he became the king. By implications, there must have been pockets of opposition to his reign, waiting for good opportunity to attack him (Interview with Elder Ojo, 2014). All these increased the number of oppositions to the peaceful reign of the king: Tax increment as veritable opportunity to achieve their long awaited desire to attack the monarch.

The slogan was that there must be tension; there must be difficult times for the King and his British collaborators before they could rescind the hike in 'head tax'. As a result of this, the British invited the police, who arrested the leaders of the revolt took them to custody in Lagos. This heightened the already tensed atmosphere (Interview with Chief Adodo).This was viewed by the Akure people as an insult that the King brought foreigners to protect himself and kill his subjects. This only aggravated 
the crisis, and people were almost unanimous about the fact that the King must abdicate the throne. However, Oba Afunbiowo deployed his legendry accommodating disposition, liberalism, diplomacy and traditional wisdom in resolving the crisis without foreign police assistance by making sure that he worked towards the release of his subjects that were arrested and detained so that relative peace could return to Akure and its environs (Interview with Chief Adodo). It was said that $\mathrm{Oba}$ Afunbiowo consulted and appeased the oracle for the peaceful resolution of the crisis. Also, he made use of his traditional chiefs and prominent indigenes in appealing to leaders of the revolt which as a corollary aided the release of the arrested leaders of the revolt.

The Nigerian government could learn from internal approach mechanism used by $\mathrm{Oba}$ Afunbiowo in resolving the Ogun Okuta that plagued the Kingdom for about three (3) months. He mobilized his Council of Chiefs and other prominent Akure sons and daughters to appeal to aggrieved people and letting them know that he was not the one that spent the money realised from the tax as alleged. This study reveals that many of the leaders of the revolt were not only aggrieved because of the tax increment, but also because of the closeness of the monarch and the benefits the princes and princesses enjoyed the period. It was argued that the community money was used to sponsor the princes and princesses to schools. The Deji and his chiefs debunked all these allegations.

Another method deployed by the king was that he threatened to abdicate the throne if the people refused to allow peace and tranquillity to reign in the kingdom. It was a common knowledge among the people that it is a taboo for a king to abdicate the throne under such a circumstance. Some of the custodians of the traditions reviewed the calamity that might bring into the Kingdom and prevailed on the people to embrace peace and dialogue. As a result of all the crisis resolution mechanisms put in place, Oba Afunbiowo was able to secure the release of all the leaders of the revolt that were kept in the British solitary confinements. This brought about relative peace and tranquillity in Akure and its environs, and the Monarch was able to resume his customary duties without harassment and intimidation.

\section{Conclusion}

The 'Ogun Okuta' of 1931was the first indigenous revolt in Akure, and it was fought against the obnoxious tax regime of the British officials and their collaborator (Oba Afunbiowo). British tax system was introduced to Akure like other part of southern Nigeria in 1917, but increment in the 'head tax' led to this revolt that defiled the sacred throne of the Deji. However, he deployed traditional wisdom in making sure that the revolt was quashed by the use of his chiefs and other notable people in Akure.

Unlike the security challenges that have bedevilled Nigeria, close to two decades, from the Niger Delta crisis that assumed horrendous dimensions in the early 1990's with the emergence of social movements and militants youths groups that began to challenge not only the state but also the policies, attitudes, and activities of the multinational organisations and corporations in the region. It is important to compare Ogun Okuta to this crisis because the Niger Delta's minority ethnic groups particularly the Ogoni and the Ijaw, like the Akure people felt they were being exploited. This is said to be as a result of frustration on the part of the people of the region arising from both state and oil companies' negligence and destruction of the Niger Delta's ecology, which is the basic structure that supports life in the region. The crisis in the Niger Delta took a new dimension about a decade ago with the kidnapping of oil workers (mostly foreign nationals), attack on oil installations wanton killings. As a result of this in 2004, the 
United State of America gave Nigerian troops military training in and around the eastern Delta port of Calabar. Also at the January 2005 African Union summit in Abuja, Chris Mullian, Britian's then Africa Minister, said London would look favourably on any request by Nigeria for help with military training or technical support in the Niger Delta region. With all these international supports and military assistance, the problems still persist till date (Ojakorotu 2008, 4, 20 and 25).

The abduction of over 250 school girls on $14^{\text {th }}$ April, 2014at Government Girls Secondary School, Chibok, in Borno State by the BokoHaram insurgents played a significant role in changing the approach to fighting the sect. Subsequent upon these superpowers including France, Britain, China, USA as well as Israel, Canada, Spain, Japan among others, promised military assistance to rescue the girls. In reaction to this development President Goodluck Jonathan opined that with the myriad support coming from countries and individuals across the globe, the days of Boko-Haram were numbered. When viewed from outside, it can appear that Boko-Haram conflicts boil down to religious differences, tensions between blocs of Muslim and Christian inhabitants. When one looks deeper, however, one finds that politics - more precisely, control of government patronage - is the primary cause of many of these conflicts. Election disputes have also led to breakdowns along Muslim and Christian lines, as was seen in the most recent polls in 2011, when youths went on the rampage in southern Kaduna state. When violence erupts in these circumstances, the genesis is usually in one group asserting control of the apparatus of government over another group just the way the Akure natives felt the Deji collaborated with the colonialists to exploit them. Since 2009, the Boko-Haram sect has grown from being a localised problem to a national threat the same way the aggrieved parties became a threat to peace in Akure. The President was so confident as if the superpowers are miracle workers, and up till now there is nothing to show that they are serious about their promise. We must be quick to point out that there is nothing like free launch anywhere and the international assistance to Nigeria might just be a pawn. Regardless of the support of the international community, exPresident Olusegun Obasanjo has opined that it would be inconceivable to have all the Chibok girls back and it would be a near miracle if it happens. However, Nigerians and the rest of the world have been galvanised to drum support for the freedom of the Chibok school girls, as little could be achieved through finger-pointing (Sha'aba 1998, 79). This paper concludes that Nigeria internal security challenges can only be resolved through concerted efforts of its citizenry not relying on external military supports.

\section{References}

Afe, A. E. and Okajare, S. T. (2001) A History of Oda and A Biography of Oba Bamidele Akosile. Akure: Olat Publishers.

Afe, A. E. and Adubuola, I. O. (2009) "The Travails of Kingship Institution in Yorubaland: A Case Study of Isinkan in Akureland" Nebula Journal 6(4): 2.

Afe, A. E. (2012) "A Historical Survey of Socio-Political Administration in Akure Region up to the Contemporary Period”. European Scientific Journal 8(18): 200-201.

Akintade, W. (2007) The Lion King and the Cubs: A Special Tribute Deji Afunbiowo Adesida I as Pioneer Architect of the Golden Century of Akure History, 1897-1957. Ibadan: International Publishers. 
Akintide, W. (2009) "Deji of Akure, Part IV: Exploring How the Institution is defined and How Much it has Changed in the Last 100 Years". Internet document, http://www.gamji.com/article3000/ news3671.htm accessed 28th November, 2015.

Aron, R. (1966) Peace and War; A Theory of International Relations. Praeger Publishers: New York.

Atandare, J. O. Iwe Itan Akure ati Agbegbe Re. Akure: Duduyemi Press.

Bogdanor, V. (1995) The Monarchy and the Constitution. London: Clarendon Press.

Boulle, L. (1996) Mediation: Principles, Process and Practice. Sydney: Butterworth.

Crotty, J. (2009) "Structural Causes of the Global Financial Crisis: A Critical Assessment of the 'New Financial Architecture”. Cambridge Journal of Economics 33(4): 563-580.

Djebah, O., Edomaruse, C., Issa-Onilu, L., Madugba, A. and Epia, O. (2003) "Royal Fathers: Their Power, Influence, Relevance". BNW News, 28th November, 2015.

Elias,T. O. (1963) The Nigeria Legal System. London: Butterworths and Co. Ltd.

Ellis,A. B. (1970) The Yoruba Speaking People of Slave Coast of West Africa. London: Curzon Press.

Esemokhai, E. O. (1986) The Legal Heritage in Nigeria. Ibadan: Olaiya Fagbemigbe Press.

Fadipe, N. A. (1970) The Sociology of the Yoruba. Ibadan: Ibadan University Press.

Grossman, H. K. (1934) “Sismondi, Jean Charles Leonard Simonde de (1773-1842)”. In: E. R. A. Seligman (ed) Encyclopaedia of the Social Sciences. New York: Macmillan Publishers, pp 69-71.

Harns, A. (1942) "Sombart and German National Socialism" Journal of Political Economy 50(6): 805-835.

Johan, M. G. (1981) On War: Concepts, Definitions, Research Data - A Short Literature Review and Bibliography. Westport CT: Greenwood Press.

Kallen, H. (1939) "Of war and peace". Social Research: 373.

Koselleck, R. (1988) Critique and Crisis: Enlightenment and the Pathogenesis of Modern Society. Oxford: Berg.

Lider, J. (1977) On the Nature of War. Saxon House: Westmead.

Marx, K. (1993) Theories of Surplus-Value: Volume IV of Capital Analysis. London: Lawrence and Wishhart.

Obaro I. and Crowder, M. (1970) West Africa Chiefs Changing Statue under Colonial Rule and Independent. Ile-Ife: University of Ife Press.

Obaro, Ikime, (2001) Groundwork of Nigerian History. Ibadan: Heinemann Publishers.

Ogunbodede, E. F and Aribigbola, A. (2003) "Traffic Management Practices and Problems in Akure, Nigeria". Indian Journal of Transport Management 27(3): 305-322.

Oguntomisin, S. O. and Ademola A. S. (2002) Reading in Nigerian History and Culture. Ibadan: Hope Press.

Ojakorotu, V. (2008) "The Internationalization of Oil Violence in the Niger Delta of Nigeria". Alternatives: Turkish Journal of International Relations 7(1): 4, 20 and 25.

Oral interview: Arifalo, S. O. (70 years), a Professor and Head of Department of History and International Studies, AdekunleAjasin University, Akungba-Akoko. He is an accomplished historian. His information has been cross-checked and found to be correct, October 1, 2009.

Oral Interview: Chief Joseph Adodo (75 years) A Community Leader: No 4, Joseph Adodo Close, Off Ijoka Road, Akure, Ondo State. 
Oral Interview: Elder Julius Oluwatayo Ojo (80 years) Retired Teacher, No. 9, Aladekemi Street, Off Ijoka Road, Akure Ondo State; 6th June, 2014.

Oral interview: W. O. Afe (73 years), No 7, Aladekemi Street,.Ijoka Road, Akure. He is an Akure Traditional Chief and he is versed in the traditions of Akure, October 30, 2003.

Schumpeter J. (1994) Capitalism, Socialism and Democracy. London: Routledge.

Sha'aba, R. A. (1998) "MOSOP and the Ogoni Struggle", In: Omotoye, Olorode et al, Ken SaroWiwa and the Crises of the Nigerian State. Lagos: CDHR.

Steven, M and Phillip, C. (2010) "Defining War for The 21st Century". Internet document, http:// www.StrategicStudiesInstitute.army.mil/ : Strategic Studies Institute Annual Strategy Conference Report.

Tillet, G. (1998) “Conflict and its Resolution”. In: HRM 540 Theory of Conflict Resolution, Study Guide Module 2: Charles Sturt University.

\title{
Проблемы безопасности в Нигерии сегодня: Огун Окута (Каменная война) 1931 года
}

в Акуре в историческом контексте

\author{
Адедайо Эммануэль Афе \\ Университет Адекунле \\ Аджазин, 23434, Нигерия
}

\begin{abstract}
Указ местного налогового управления от 1917 года виервые ввел систему прямого налогообложения в Южной Нигерии. Это нововведение было встречено сопротивлением со сторонь людей в некоторых городах, в том числе таких, как Аба, Исейин и Акуре. Сбор налогов привел $\kappa$ войне, иироко известной как Огун Окута (Каменная война) в 1931 году в городе Акуре и его окрестностях. В данной статье обсуждается роль, которую сыграл правитель провинции Акуре Оба Афунбиово Адесида І в условиях кризиса. Исследование, проведенное автором, является крайне важным, так как правление Оба Адесида описано лишь в нескольких ограниченных источниках как мирное, но результаты данного исследования показывают обратное, а именно то, что подданные монарха порочили его за предполагаемую роль в сотрудничестве с британскими властями во введении непосильного налога на население. Это исследование также показало, что были и другие факторы, послужившие причинами восстаний, начавшихся на почве нового налогообложения. Методика исследования основана на критическом анализе материалов, взятых из устных и письменных источников. Исследование выявило бытующее мнение о том, что британское вмешательство усугубило внутренний кризис в пределах королевства. В статье делается следуюший вывод: вопросы внутренней безопасности Нигерии должны решаться правительством Нигерии без вмешательства внешних военных сил или разведки.
\end{abstract}

Ключевые слова: налоги, кризис, война, резолючия, монарх.

Научная спечиальность: 07.00.00 - исторические науки. 